\title{
Widening medical students' exposure and confidence toward resuscitation management and discussions
}

\author{
Aniruddh Shenoy \\ Fahad Mohammad \\ College of Medical and Dental \\ Sciences, University of Birmingham, \\ Birmingham, UK
}

This article was published in the following Dove Press journal: Advances in Medical Education and Practice

\section{Dear editor,}

We would like to thank Aggarwal and Khan ${ }^{1}$ on their review of medical students' experiences of resuscitation and discussions surrounding resuscitation status, which we read with great interest. As medical undergraduates ourselves, we found it insightful and valuable to read the opinions of fellow students on such an essential and delicate matter.

Tomorrow's Doctors, the guidance provided to medical undergraduates by the General Medical Council, states that students should be able to "provide cardiopulmonary resuscitation (CPR) or direct other team members to carry out resuscitation". ${ }^{2}$ However, basic life support taught in accordance with this guidance is unlikely to replicate the stress and pressure of performing CPR on real patients, as detailed by the students reflecting on the realities of CPR. More eye opening was the scarcity with which students had encountered such an important medical experience (11 of the 20 interviewed). Considering how sporadic and urgent cardiopulmonary arrest is, it is unlikely that any progress will be made toward increasing students' exposure to CPR. However, we believe that more steps could be taken to simulate the urgency of having to perform CPR, to provide more representative preparation for students. For instance, Gokhale et $\mathrm{al}^{3}$ found that employing the strategy of "on the spot" simulation of CPR led to a statistically significant improvement in CPR knowledge post-session and all participants reported increased confidence in performing resuscitation in the future. Therefore, we argue that incorporating such measures to simulate the spontaneity of real CPR will serve to develop necessary skills and confidence in a safe environment.

The students' accounts on the topic of Do not attempt cardiopulmonary resuscitation particularly resonated with us, with personal experiences of being turned away from such conversations. As a career dedicated to preserving life, discussions around palliation and end-of-life management have traditionally not featured heavily in medical education. The sensitivity around the subject of end-of-life management and the necessity for effective communication on the topic were demonstrated in the infamous media dissection of the Liverpool Care Pathway. It has been demonstrated that direct experience with patients at the end of their lives gives medical students a more positive attitude toward and better knowledge of end-of-life care. ${ }^{4}$ One key factor hampering the availability of such opportunities to students is the patient's right to privacy at such a significant period in their life, which must be respected above everything else. However, we believe from our experience, there is a growing appreciation among patients that
Correspondence: Aniruddh Shenoy College of Medical and Dental Sciences, University of Birmingham, Edgbaston, Birmingham BI5 2TT, UK

Email axs1084@student.bham.ac.uk 
students are a legitimate link in the chain of a health care team, and will go on to bear the responsibility of caring for similar patients in the future. It is our personal opinion that this shift in attitude is born out of the burgeoning culture promoting transparency and patient involvement in health care. As such, we feel that the best way to widen students' exposure to end-of-life discussions is to maintain this openness and compassion to foster the trust needed for patients to allow students into such a momentous time in their lives.

\section{Disclosure}

The authors report no conflicts of interest in this communication.

\section{References}

1. Aggarwal A, Khan I. Medical students' experiences of resuscitation and discussions surrounding resuscitation status. Adv Med Educ Pract. 2018;9:31-37.

2. Tomorrow's doctors. General Medical Council; 2009. Available from: http://www.ub.edu/medicina_unitateducaciomedica/documentos/TomorrowsDoctors_2009.pdf. Accessed January 29, 2018.

3. Gokhale O, Htyn M, Stafford N, Jones K. P20 Undergraduate medical student "on the spot" cardiopulmonary resuscitation simulation training [Internet]. BMJ Simulation \& Technology Enhanced Learning. 2018. Available from: http://stel.bmj.com/content/3/Suppl_2/A52.3. Accessed January 29, 2018.

4. Anderson W, Williams J, Bost J, Barnard D. Exposure to death is associated with positive attitudes and higher knowledge about end-of-life care in graduating medical students. J Palliat Med. 2008;11(9):1227-1233.

Dove Medical Press encourages responsible, free and frank academic debate. The content of the Advances in Medical Education and Practice 'letters to the editor' section does not necessarily represent the views of Dove Medical Press, its officers, agents, employees, related entities or the Advances in Medical Education and Practice editors. While all reasonable steps have been taken to confirm the content of each letter, Dove Medical Press accepts no liability in respect of the content of any letter, nor is it responsible for the content and accuracy of any letter to the editor.

\section{Publish your work in this journal}

Advances in Medical Education and Practice is an international, peerreviewed, open access journal that aims to present and publish research on Medical Education covering medical, dental, nursing and allied health care professional education. The journal covers undergraduate education, postgraduate training and continuing medical education including emerging trends and innovative models linking education, research, and health care services. The manuscript management system is completely online and includes a very quick and fair peer-review system. Visit http://www.dovepress.com/testimonials.php to read real quotes from published authors.

Submit your manuscript here: http://www.dovepress.com/advances-in-medical-education-and-practice-journal 